[Agr. Biol. Chem., Vol. 36, No. 2, p. 285 293, 1972]

\title{
Production of Alkaline Enzymes by Alkalophilic Microorganisms
}

\section{Part III. Alkaline Pectinase of Bacillus No. P-4-N}

\author{
By Koki HoRikoshi \\ The Institute of Physical and Chemical Research \\ Wako-shi, Saitama-ken 351
}

Received August 6, 1971

\begin{abstract}
Bacillus Vo. P-4-N isolated from soil produced an alkaline polygalacturonase (APGase) in alkaline media. The characteristic point of this microorganism was especially good growth in alkaline media, and that very poor growth was detected in neutral media such as nutrient broth. An important factor for the production of APGase was the addition of manganese to the medium containing sodium carbonate, which was also another imporant factor. The APGase of Bacillus No. P-4-N was purified by Sephadex G-100 and DEAEcellulose columns followed by Sephadex G-200 gel filtration. The enzyme was most active at $\mathrm{pH} 10 \sim 10.5$ and stable $\mathrm{pH}$ was about 6 . The enzyme was heat stable: about $80 \%$ of the activity remained after heating at $80^{\circ} \mathrm{C}$ for $5 \mathrm{~min}$. Calcium ion was effective to stimulate the activity and to stabilize the enzyme. The molecular weight estimated by Sephadex gel filtration method was $6 \sim 7 \times 10^{4}$. The enzyme was completely inactivated by EDTA, but not by urea, $\mathrm{VaCl}$ and PCMB. The enzyme split polygalacturonic acid at random and yielded galacturonic acid, digalacturonic acid and higher oligogalacturonic acids. If the enzyme is a single entity, it is a type of liquefying APGase.
\end{abstract}

In the previous papers of this series, ${ }^{1,21}$ it has been reported that a certain species of bacteria isolated from soil in Japan can grow in alkaline media containing high concentration of sodium carbonate or sodium bicarbonate. Bacillus No. 221 accumulates a large amount of alkaline protease having the optimum $\mathrm{pH}$ at 11.5.' Bacillus No. A-40-2 produces an alkaline amylase which has the optimum $\mathrm{pH}$ at $10.5 .^{21}$

By the analogous method, a strain producing alkaline polygalacturonase (APGase) has been isolated.

This paper deals with the isolation and characterization of the strain, Bacillus No. P-4-N which produces APGase, and some properties of the enzyme are also discussed.

\section{MATERIALS AND METHODS}

Medium to isolate APGase-producing microorganisms. A pectin medium was used to isolate the bacteria producing APGase: pectin, $30 \mathrm{~g}$; polypeptone, $5 \mathrm{~g}$; yeast extract (Difco), $5 \mathrm{~g} ; \mathrm{K}_{2} \mathrm{HPO}_{4}, 1 \mathrm{~g} ; \mathrm{MgSO}_{4} \cdot 7 \mathrm{H}_{2} \mathrm{O}$, $0.2 \mathrm{~g} ; \mathrm{MnSO}_{4} \cdot 7 \mathrm{H}_{2} \mathrm{O}, 0.05 \mathrm{~g} ; \mathrm{Na}_{2} \mathrm{CO}_{3}, 10 \mathrm{~g}$ and 1 liter of water. Sodium carbonate was sterilized separately and added to the medium. The pectin medium was solidified by the addition of agar $(1.5 \% \mathrm{w} / \mathrm{v})$, if necessary.

Isolation method of alkalophilic bxteria producing APGase. A small amount of soil was suspended in sterilized water and spread on the pectin agar plates. The plates were incubated at $37^{\circ} \mathrm{C}$ for $48 \mathrm{hr}$. Colonies isolated were inoculated into the pectin medium and incubated at $37^{\circ} \mathrm{C}$ for 3 days with continuous shaking. Pectinase activities of the culture fluid were measured at $\mathrm{pH}$ values of 7.0 and 10.0. Bacillus No. P- $4-\mathrm{N}$ was isolated as a potent producer for alkaline APGase from about 100 colonies.

Characterization and identification of bacteria. Morphological properties and taxonomic characteristics of the bacteria were investigated according to the method described in "Aerobic Sporeforming Bacteria"'s and "Bergey"s Manual of Determinative Bacteriology." 
Unless stated otherwise, media used for the identification were supplemented with $106 \mathrm{Na}_{2} \mathrm{CO}_{3}$.

Preparation of a crude encyme solution. Bacillus No. P-4-N was grown aerobically at $37^{\circ} \mathrm{C}$ in the tested media. After 2 to 3 days of incubation with continuous shaking, cells were removed by centrifugation at $6,000 \times g$ for $10 \mathrm{~min}$ and the supernatant fluid was examined as a crude enzyme solution.

Assay of APGase. The enzyme $(0.01 \mathrm{ml})$ containing up to $20 \mathrm{mU}$ of APGase in $0.01 \mathrm{~m}$ Tris- $\mathrm{HCl}$ buffer ( $\mathrm{pH} 7.0$ ) was mixed with $0.2 \mathrm{ml}$ of $1 \% 0$ pectic acid containing $1 \mathrm{mM} \mathrm{CaCl}_{2}$ (made up with $0.05 \mathrm{M}$ glycine$\mathrm{NaOH}-\mathrm{NaCl}$ buffer of $\mathrm{pH} 10.0)$. After $10 \mathrm{~min}$ incubation at $40^{\circ} \mathrm{C}, 1 \mathrm{ml}$ of dinitrosalycilic acid solution ${ }^{5}$ was added, and the mixture was heated in a boiling water-bath for $5 \mathrm{~min}$, and then $4 \mathrm{ml}$ of water were added to it. After centrifugation at $1,000 \times g$ for 10 min, an optical density of the supernatant fluid was measured at 510 m $\ell$. One unit of the enzyme activity is difined as the amount of enzyme which produces one $\mathrm{mg}$ of reducing sugar calculated as galacturonic acid per minute under the above condition.

Measurement of viscosity. Viscosimetric measurements were carried out in Ostwald viscosimeters. Pectic acid solution containing $1 \mathrm{mM} \mathrm{CaCl}_{2} \quad(0.05 \mathrm{M}$ glycine buffer, $\mathrm{pH}$ 9.0) was mixed with the enzyme and the enzymatic action was expressed as per cent viscosity change. This is equivalent to the Abbauzahl $\lambda$ of Weber and Deuel 6 ? which is calculated as follows:

$A=V_{0}-V_{t} / V_{0}-V_{s} \times 100$

$V_{0}=$ flow time in seconds of pectic acid + inactivated enzyme

$V_{t}=$ flow time in seconds at reaction time of pectic acid + active enzyme

$V_{s}=$ flow time in seconds of the buffer + inactivated enzyme.

To inactivate the enzyme, the enzyme solution was heated at $100^{\circ} \mathrm{C}$ for $10 \mathrm{~min}$.

Assay of pectinesterase activity. Five $\mathrm{ml}$ of $1.0^{\circ} \mathrm{O}$ pectin solution were mixed with $0 . \mathrm{lml}$ of test solution (5U in APGase) at $\mathrm{pH} 10.0$, and the increase in acidity of the reaction mixture at $40^{\circ} \mathrm{C}$ was measured using a Hiranuma RAT 101 automatic titrator.

Assay of trans-eliminase activities toward pectin and pectic acid. Three $\mathrm{ml}$ of $1.0 \%$ pectin solution $(\mathrm{pH}$
10.0 , glycine buffer, $0.05 \mathrm{~m}$ ) and $0.05 \mathrm{ml}$ of test solution (2.5 $\mathrm{U}$ in APGase) were mixed and an absorbancy at $235 \mathrm{~m} \mu$ was measured by a Hitachi double beam spectrophotometer at room temperature for 2 hr. Polygalacturonic acid trans-eliminase was measured in the similar way except that pectic acid was used as the substrate instead of pectin.

Protein concentration. Protein concentration was estimated by the method of Warburg and Christian.7?

Identification of enzymatic digest of pectic acid. The hydrolyzate was chromatographed on Whatman No. 1 paper with the solvent system of butanol-acetic acid-water $(2: 1: 1 \mathrm{v} / \mathrm{v})$ at room temperature. Ammoniacal silver nitrate was used as a spraying reagent.

Reagents. Pectin from citrus and pectic acid were obtained from Wako Pure Chemical Co., Ltd, Osaka.

\section{RESULTS}

\section{Characters of Bacillus No. P-4-N}

The isolated strain No. P-4-N was an aerobic, sporeforming, gram positive, motile, rad-shaped bacterium, and pertirichous flagella. It is clear that the bacterium should belong to the genus Bacillus. The characteristic point of the bacteria was that it grew well in alkaline media rather than neutral one such as nutrient broth, the optimal $\mathrm{pH}$ for growth was about 10.

Table I summarizes the morphological and cultural characteristics of the strain No. P-4-N. Taxonomic position of this strain will be reported elsewhere.

\section{Culture conditions for production of APGase}

Culture conditions for APGase production were examined in the media containing various amounts of sodium carbonate. Requirement of minerals was also tested. APGase activity after $48 \mathrm{hr}$ ' cultivation was assayed. The results are shown in Table II, which indicates that the addition of carbonate and manganase salts is an important factor for the production of the APGase. The formation of APGase was adaptive, because no activity of APGase 
Table 1. Morphological, Cultural, and Biochemical Characteristics of Strain P-4-N

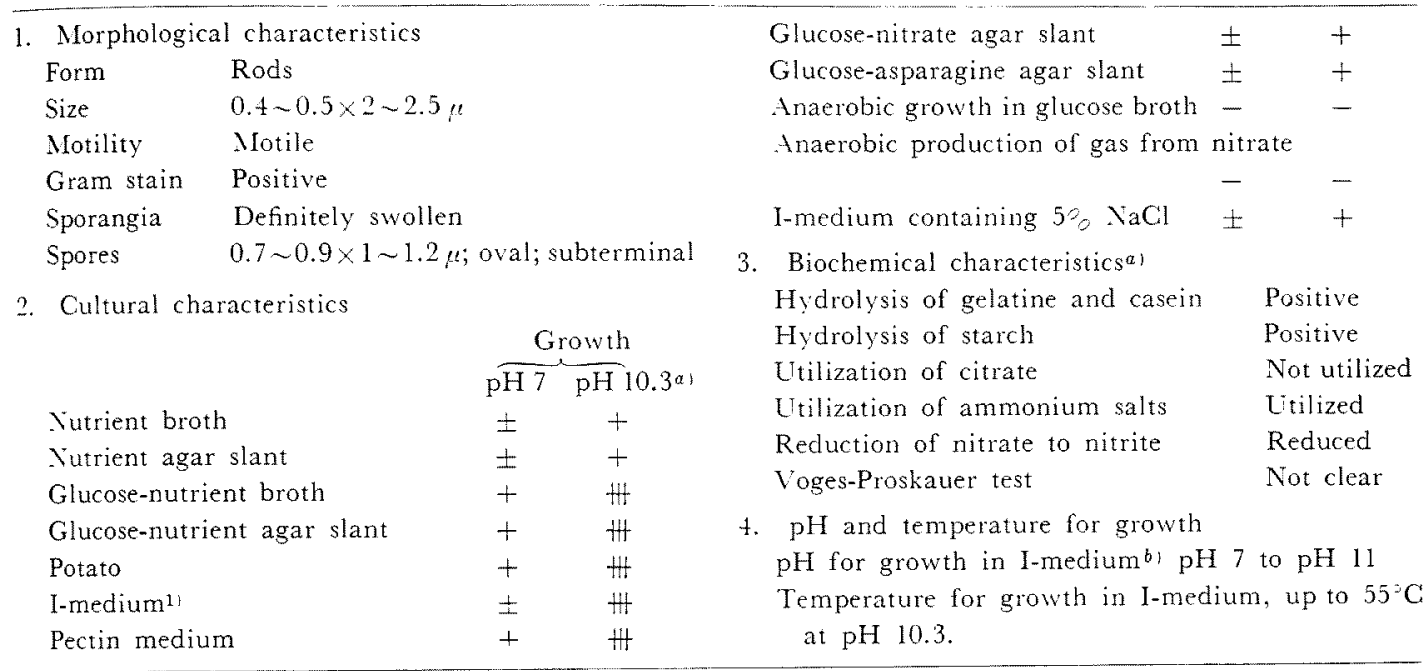

a) $\mathrm{Na}_{2} \mathrm{CO}_{3}(10)$ was added to the media.

b) $\mathrm{pH}$ in the I-medium was adjusted by adding $\mathrm{HCl}$ or $\mathrm{NaOH}$.

- , indicates no growth; \pm , very poor growth; + , poor growth; $\#$, normal growth; H, growth abundant.

\section{Table 11. Culture Conditions for Production of APGase}

Bacillus No. P-4-N was grown aerobically at $37 \% \mathrm{C}$ in the tested media. After 2 days incubation with shaking, APGase activity was measured. $\mathrm{MnSO}_{4} 7 \mathrm{H}_{2} \mathrm{O}$ is expressed as $\mathrm{Mn}^{2} ; \mathrm{FeSO}_{4} 7 \mathrm{H}_{2} \mathrm{O}, \mathrm{Fe}^{2+}$; $\mathrm{CaCl}_{2} 2 \mathrm{H}_{2} \mathrm{O}, \mathrm{Ca}^{2}+$

\begin{tabular}{|c|c|c|c|c|c|c|c|}
\hline $\begin{array}{c}\text { Pectin } \\
(0)\end{array}$ & $\begin{array}{c}\text { Peptone } \\
(0)\end{array}$ & $\begin{array}{c}\mathrm{Na}_{2} \mathrm{CO}_{3} \\
(0)\end{array}$ & $\begin{array}{l}\text { Initial } \\
\mathrm{pH}\end{array}$ & $\begin{array}{c}\mathrm{Mn}^{2+} \\
\left(0_{0}\right)\end{array}$ & $\begin{array}{l}1 e^{2+} \\
(0)\end{array}$ & $\begin{array}{c}\mathrm{Ca}^{2+} \\
(0)\end{array}$ & $\begin{array}{c}\text { APGase } \\
\text { (U) }\end{array}$ \\
\hline 1 & 0.5 & 0 & 7.2 & 0.005 & 0 & 0 & 0.2 \\
\hline 2 & 0.5 & 0 & 7.2 & 0.005 & 0 & 0 & 0.2 \\
\hline 3 & 0.5 & 0 & 7.2 & 0.005 & 0 & 0 & 0.2 \\
\hline 1 & 0.5 & 1 & 10.2 & 0.005 & 0 & 0 & 0.5 \\
\hline 2 & 0.5 & 1 & 10.2 & 0.005 & 0 & 0 & 4.5 \\
\hline 3 & 0.5 & 1 & 10.2 & 0.005 & 0 & 0 & 7.2 \\
\hline 3 & 0.5 & 1.5 & 10.4 & 0.005 & 0 & 0 & 8.5 \\
\hline 3 & 0.5 & 2.0 & 10.6 & 0.005 & 0 & 0 & 2.3 \\
\hline 3 & 0.5 & 2.5 & 10.7 & 0.005 & 0 & 0 & 1.5 \\
\hline 3 & 0.5 & 1.5 & 10.4 & 0 & 0 & 0 & 2.1 \\
\hline 3 & 0.5 & 1.5 & 10.4 & 0.01 & 0 & 0 & 5.5 \\
\hline 3 & 0.5 & 1.5 & 10.4 & 0.001 & 0 & 0 & 5.0 \\
\hline 3 & $0 . \overline{5}$ & 1.5 & 10.4 & 0.005 & 0.005 & 0 & 8.0 \\
\hline 3 & 0.5 & 1.5 & 10.4 & 0.005 & 0.005 & 0.005 & 6.0 \\
\hline
\end{tabular}

(less than $0.2 \mathrm{U} / \mathrm{ml}$ ) was detected in media containing glucose or starch instead of pectin.
Purification of the enzyme

Bacillus No. P-4-N was grown aerobically at $37 \mathrm{C}$ in the pectin medium described above. 


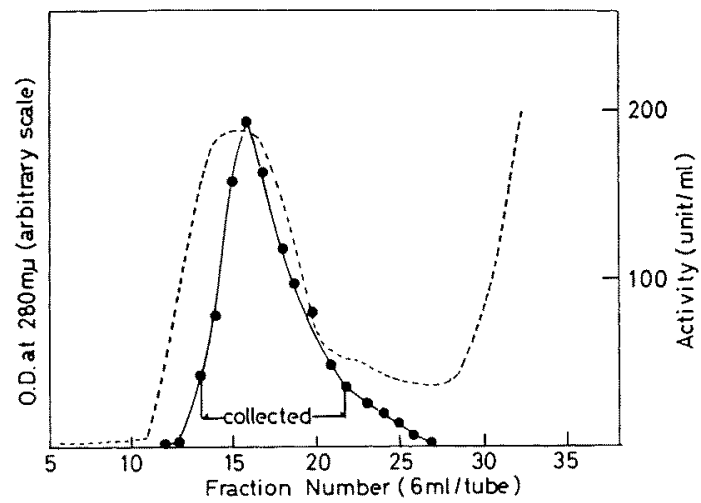

Fig. 1. Column Chromatogram on Sephadex G-100.

Column, $2.5 \times 45 \mathrm{~cm}$; flow rate, $35 \mathrm{ml} / \mathrm{hr} ;$ O.D. at $280 \mathrm{~m} \mu$ was monitored by an Ohtake UV analyzer (dotted line); open circle, APGase activity.

After 2 days' cultivation with shaking, the culture fluid $(1,000 \mathrm{ml})$ was centrifuged at $6,000 \times g$ for $10 \mathrm{~min}$. The supernatant fluid $(6.5 \mathrm{U} / \mathrm{ml})$ was divided into dialysis bags and concentrated by dipping in polyethylene glycol No. 6,000. The concentrates $(30 \mathrm{ml})$ were passed through a Sephadex G-100 column $(2.5 \times 45 \mathrm{~cm})$ which was equilibrated with 0.01 M phosphate buffer ( $\mathrm{pH}$ 7.6). A typical elution profile is shown in Fig. 1. The active fractions were collected and loaded onto a DEAE-cellulose column $(3,30 \mathrm{~cm})$ equilibrated with $0.01 \mathrm{M}$ phosphate buffer ( $\mathrm{pH}$ 7.6). After the column was successively washed with 0.01 M phosphate buffer ( $\mathrm{pH} 7.6$ ) containing $0.1 \mathrm{M}$ $\mathrm{NaCl}$, the APGase was eluted with a linear gradient increase in $\mathrm{NaCl}$ at flow rate of 50 $\mathrm{ml} / \mathrm{hr}$. A linear gradient was obtained by using $400 \mathrm{ml}$ each of $0.1 \mathrm{M}$ and $0.4 \mathrm{M} \mathrm{NaCl}$ in $0.01 \mathrm{M}$ phosphate buffer $(\mathrm{pH} 7.6) ; 7 \mathrm{ml}$ fractions

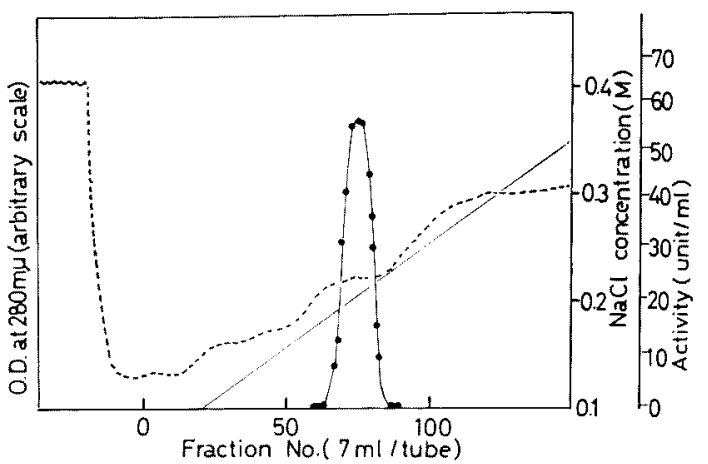

FIG. 2. Column Chromatogram on DEAE-cellulose.

Column, $3 \times 30 \mathrm{~cm}$; load, about $160 \mathrm{mg}$; flow rate, $60 \mathrm{ml}$ /hr; O.D. at $280 \mathrm{~m} \mu$ was monitored by an Ohtake UV analyzer (dotted line); closed circle, APGase activity; solid line, concentration of $\mathrm{NaCl}$.

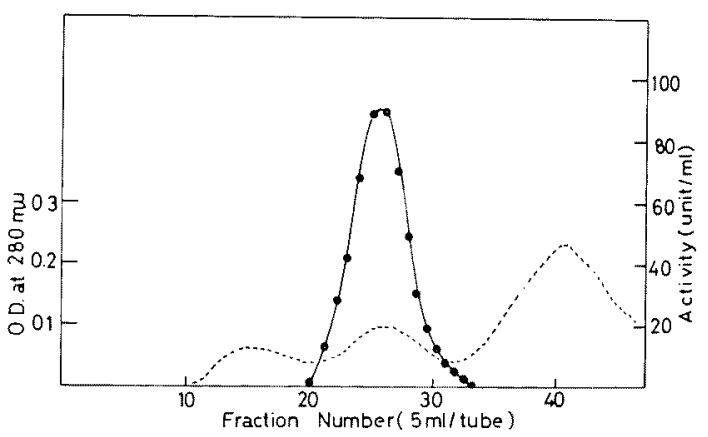

FIG. 3. Sephadex G-200 Column Chromatogram of Partially Purified Enzyme.

Column, $2.5 \times 45 \mathrm{~cm}$; flow rate, $30 \mathrm{ml} / \mathrm{hr}$; open circle, APGase activity; dotted line, O.D. at 280 mu.

were collected and each fraction was assayed. A typical chromatogram is shown in Fig. 2. Fractions containing APGase were collected

TABLE III. PURIFication OF APGase

\begin{tabular}{lcccccc} 
& $\begin{array}{c}\text { Volume } \\
(\mathrm{mI})\end{array}$ & $\begin{array}{c}\text { Activity } \\
(\mathrm{U} / \mathrm{ml})\end{array}$ & $\begin{array}{c}\text { Total activity } \\
(\mathrm{U})\end{array}$ & $\begin{array}{c}\text { Total protein } \\
(\mathrm{mg})\end{array}$ & $\begin{array}{c}\text { Specific activity } \\
(\mathrm{U} / \mathrm{mg} \text { protein) }\end{array}$ & $\begin{array}{c}\text { Recovery } \\
\left(O_{0}\right)\end{array}$ \\
\hline Culture fluid & 1,000 & 6.5 & 6,500 & 2,100 & 3.1 & 100 \\
Sephadex G-100 & 60 & 85 & 5,100 & 164 & 33.1 & 80 \\
DEAE-cellulose & 70 & 46.5 & 3,250 & 9.3 & 350 & 50 \\
Sephadex G-200 & 55 & 47.2 & 2,600 & 2.7 & 950 & 40 \\
\hline
\end{tabular}


and concentrated by polyethylene glycol method mentioned above. The enzyme preparation $(7 \mathrm{ml})$ was passed through a Sephadex G-200 column $(2.5 \times 45 \mathrm{~cm})$ equilibrated with $0.05 \mathrm{M}$ Tris- $\mathrm{HCl}$ buffer $(\mathrm{pH} 7.5)$. Figure 3 shows a typical elution pronle of the enzyme. The APGase was purified about 300-fold by these treatments. The results are shown in Table III. The following experiments were carried out by using this preparation.

\section{Molecularweight and ultraviolet absorption spectrum}

An estimation of the molecular weight of the enzyme was made by using a calibrated Sephadex G-100 column ${ }^{8 !}(1.6 \times 65 \mathrm{~cm})$ equilibrated with $0.01 \mathrm{M}$ phosphate buffer $(\mathrm{pH} 7.0$ ) containing $0.1 \mathrm{M} \mathrm{NaCl}$. On the column, $1 \mathrm{ml}$ of purified APGase (20 U) was applied, and the flow rate was $35 \mathrm{ml} / \mathrm{hr}$. On the assumption that the APGase conforms to linear relationship between the elution volume and the $\log$ of the molecular weight, the molecular weight is approximately $6 \sim 7 \times 10^{4} \quad$ Ultraviolet absorption spectrum of the enzyme showed a typical UV absorption of protein. The ratio of absorption at $280 \mathrm{~m} \mu$ to $260 \mathrm{~m} \mu$ was about 1.4.

Effect of $\mathrm{CaCl}_{2}$ on activity of $A P G a s e$, and relation of enzyme concentration and reaction rate

The enzyme $(15 \mathrm{mU})$ was mixed with 0.2 $\mathrm{ml}$ of $1, \%$ pectic acid $(0.05 \mathrm{M}$ glycine- $\mathrm{NaOH}$ $\mathrm{NaCl}, \mathrm{pH}$ 10.0) containing various concentrations of $\mathrm{CaCl}_{2}$, and enzyme activity was measured. As shown in Fig. 4, maximal activity was observed in $1 \mathrm{~mm}$. Only $10 \%$ of activity was detected in the absence of $\mathrm{CaCl}_{2}$. Thus, routine assays were always made in the reaction mixture with $1 \mathrm{~mm} \mathrm{CaCl}{ }_{2}$. Various concentrations of the enzyme were mixed with $0.2 \mathrm{ml}$ of $1 \%$ pectic acid $(0.05 \mathrm{M}$ glycine buffer, $\mathrm{pH} 10.0$ ) containing $1 \mathrm{mM} \mathrm{CaCl}$. As shown in Fig. 5, under the condition of the assay described above, a straight-line relationship was maintained between reducing power and enzyme concentration (up to $20 \mathrm{mU}$ ).

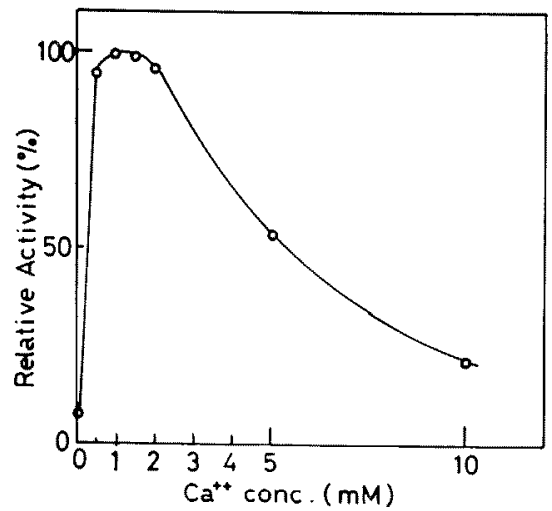

FIG. 4. Effect of $\mathrm{CaCl}_{2}$ on APGase Activity.

APGase $(15 \mathrm{~mL})$ was mixed with $0.2 \mathrm{ml}$ of $1 \%$ pectic acid $(\mathrm{pH} 10.0)$ containing indicated amounts of $\mathrm{CaCl}_{2}$. The maximum activity is expressed as $100 \%$.

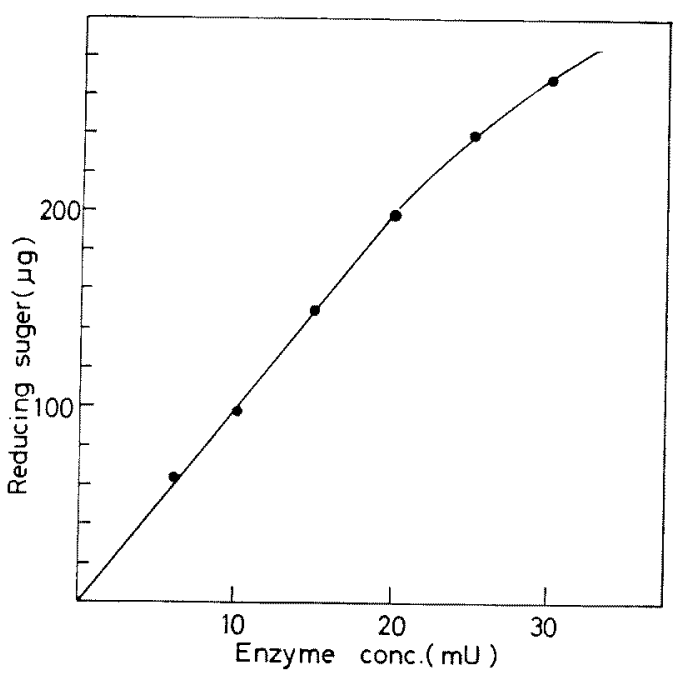

FIG. 5. Relation of Enzyme Concentration and Reaction Rate.

Time course of hydrolysis

About $0.2 \mathrm{U}$ of the enzyme $(0.15 \mathrm{ml})$ was mixed with $3 \mathrm{ml}$ of $10_{\circ}^{\circ}$ pectic acid or pectin containing $1 \mathrm{mM} \mathrm{CaCl} 2$ ( $\mathrm{pH} 10.0,0.05 \mathrm{M}_{\text {glycine }}$ buffer). Aliquots $(0.2 \mathrm{ml})$ of the reaction mixture were periodically taken, and reducing sugars produced were determined. 


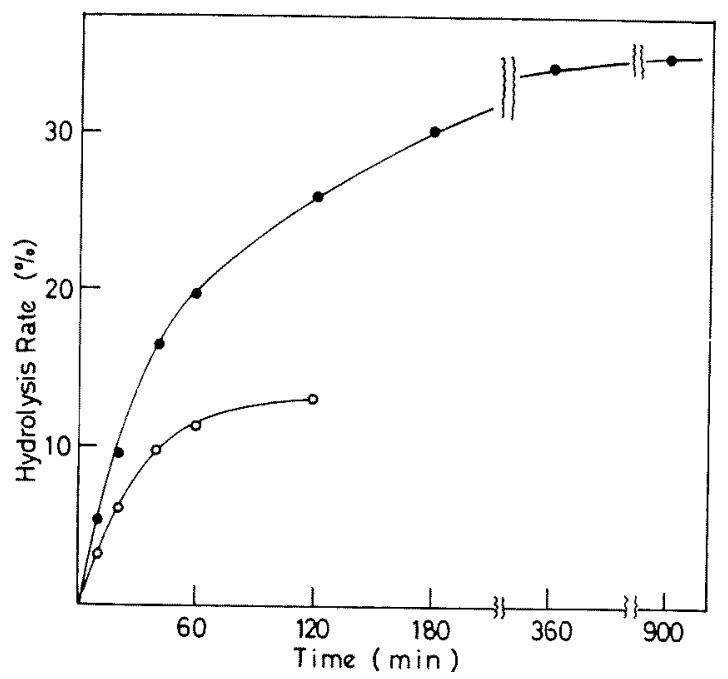

FIG. 6. Time Course of Hydrolysis of Pectin and Pectic Acid.

About $0.2 \mathrm{U}$ of the enzyme $(0.15 \mathrm{ml})$ was mixed with $3 \mathrm{ml}$ of pectic acid or pectin solution of $\mathrm{pH}$ 10.0 and incubated at $40^{\circ} \mathrm{C}$. Open circle, pectin; closed circle, pectic acid.

As shown in Fig. 6, maximum degree of hydrolysis was about $35 \%$. Addition of the enzyme $(0.2 \mathrm{U})$ did not cause further liberation of reducing sugar. Pectin was also hydrolyzed with the enzyme, although the velocity of hydrolysis was almost $50 \%$ of that of pectic acid.

Effects of $p H$ on activity and on stability of the enzyme

Figure 7 shows effect of $\mathrm{pH}$ on APGase activity. The enzyme is most active at $\mathrm{pH}$ 10.0. Stability of the enzyme was investigated in buffer solution of various $\mathrm{pH}$ values containing $1 \mathrm{mM} \mathrm{CaCl}_{2}$. The mixture was incubated at $70^{\circ} \mathrm{C}$ for $10 \mathrm{~min}$, and the residual activity was determined at $\mathrm{pH} 10.0$. As shown in Fig. 8, the enzyme is most stable at $\mathrm{pH} 6.5$.

Temperature optimum for enzyme action and thermal stability

The optimum temperature was determined

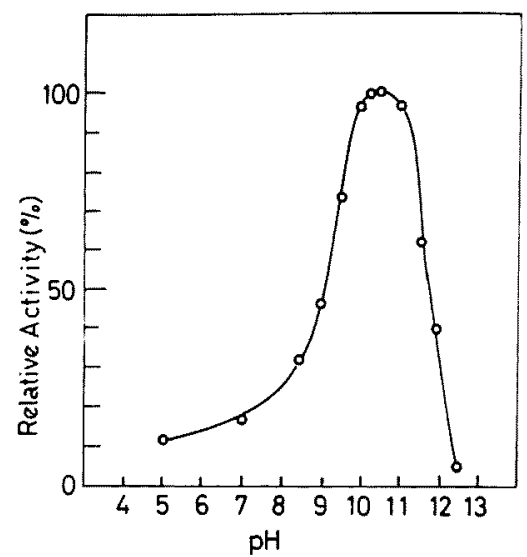

FIG. 7. Optimum pH of APGase.

The $\mathrm{pH}$ was adjusted with $0.1 \mathrm{M}$ Tris-maleate buffer (pH $5 \sim 8.5), \quad 0.1 \mathrm{~m}$ glycine- $\mathrm{NaOH}-\mathrm{NaCl}$ buffer ( $\mathrm{pH} \quad 8.5 \sim 11.5$ ) and $0.1 \mathrm{M} \quad \mathrm{Na}_{2} \mathrm{CO}_{3}-\mathrm{NaOH}$ bufier ( $\mathrm{pH} 11.5 \sim 12$ ).

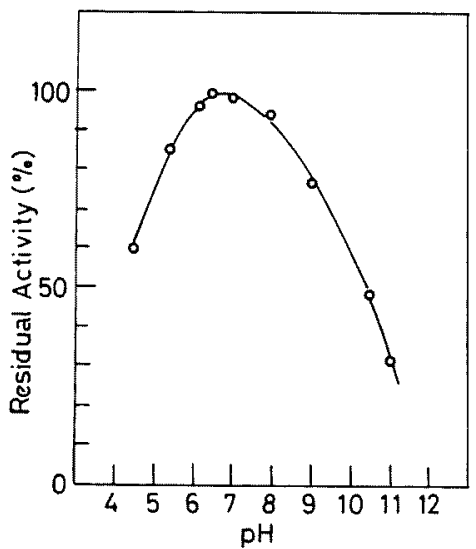

FIG. 8. Effect of $\mathrm{pH}$ on Stability.

The following buffer systems were used: $0.05 \mathrm{M}$ Tris-maleate ( $\mathrm{pH} 5 \sim 8.5$ ) and $0.05 \mathrm{M}$ glycine- $\mathrm{NaOH}$ $\mathrm{NaCl}(\mathrm{pH} 9 \sim 11$ ). The reaction mixture was incubated at $70^{\circ} \mathrm{C}$ for $10 \mathrm{~min}$ and the residual activity was determined.

by varying the reaction temperature. In Fig. 9 , the activity at $40^{\circ} \mathrm{C}$ was expressed as $100^{\circ}$. The activity at $65^{\circ} \mathrm{G}$ was about $700 \%$. To examine the thermal stability, the enzyme was dissolved in $0.05 \%$ Tris-maleate buffer ( $\mathrm{pH}$ 6.5), and the solution was heated at the 


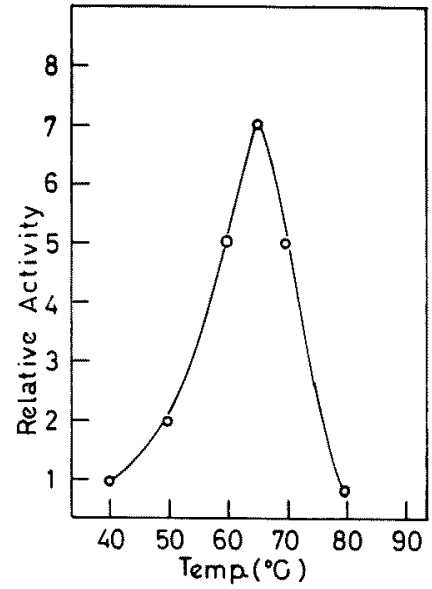

FIG. 9. Optimum Temperature for Enzyme Action.

Reaction was carried out at $\mathrm{pH} 10.0$ for 10 min in the presence of $1 \mathrm{mM} \mathrm{Ca}^{2-}$.

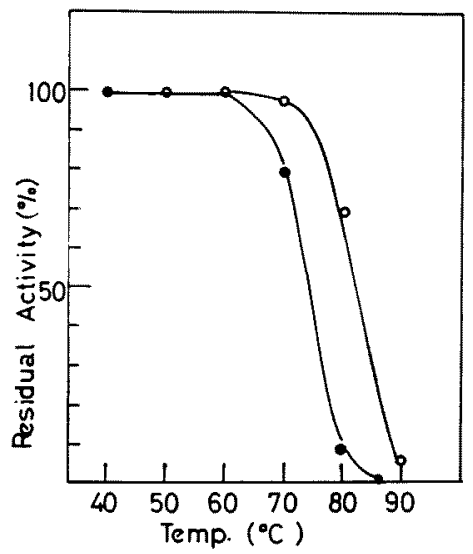

Fig. 10. Thermal Stability of the Enzyme.

Open circle, in the presence of $\mathrm{Ca}^{2-}$; closed circle, in the absence of $\mathrm{Ca}^{2+}$. See the text for the experimental details.

indicated temperatures for $10 \mathrm{~min}$, the residual activity being measured at $\mathrm{pH} 10.0$. Incubation was done in the presence or absence of $\mathrm{Ca}^{2+}(5 \mathrm{~mm})$. As shown in Fig. 10, the enzyme was stable up to $70^{\circ} \mathrm{C}$ in the presence of $\mathrm{Ca}^{2+}$

\section{Effect of inhibitors}

The enzyme was incubated with the reagents in $0.05 \mathrm{M}$ glycine buffer $(\mathrm{pH} 10.0)$ at $30^{\circ} \mathrm{C}$ for $30 \mathrm{~min}$ and the residual activity was determined. The enzyme was completely inactivated by $10^{-2} \mathrm{M}$ of EDTA (ethylendiaminetetraacetic acid). Urea $(8 \mathrm{M}), 0.3 \mathrm{M}$ of $\mathrm{NaCl}$ and $10^{-4} \mathrm{M}$ of PCMB ( $p$-chloromercuribenzoate) did not show any inhibitory effect.

Reduction in viscosity of pectic acid by the enzyme

The experiment was done at $\mathrm{pH} 9.0$, because the viscosity at $\mathrm{pH} 10.0$ was too low to determine. To $5 \mathrm{ml}$ of 40 pectic acid solution

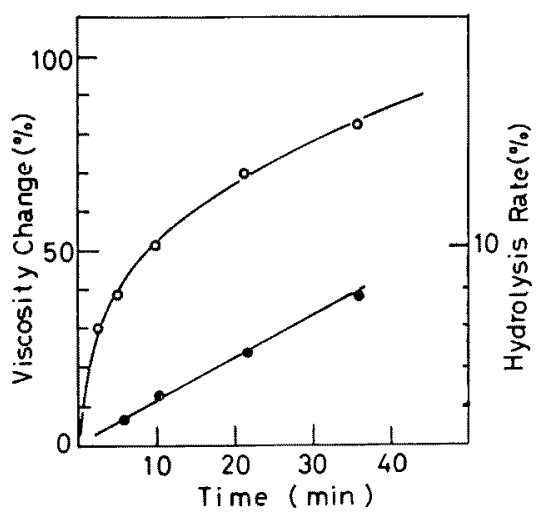

FIG. 11. Decrease in Viscosity and Increase in Reducing Power of Pectic Acid Solution by Incubation with the Enzyme.

Pectic acid solution $(5 \mathrm{ml}, 4 \%$, pH 9.0) was hydrolyzed with $0.1 \mathrm{ml}$ of the enzyme $(0.1 \mathrm{~L})$. See the text for further details. Open circle, viscosity; closed circle, hydrolysis rate.

containing $1 \mathrm{mM} \mathrm{CaCl}$ (made up with $0.05 \mathrm{M}$ glycine buffer, $\mathrm{pH} 9.0), 0.1 \mathrm{ml}$ of the enzyme $(0.1 \mathrm{U})$ was added. Decrease in viscosity and increase in reducing power by the enzyme are shown in Fig. 11. After $10 \mathrm{~min}$ incubation, about $50 \%$ of viscosity decreased, but hydrolysis degree which was calculated by reducing sugars liberated was only $2.5 \%$.

Mode of action of the enzyme on pectic acid

About $10 \mathrm{mg}$ of pectic acid were dissolved in $1 \mathrm{ml}$ of water containing $1 \mathrm{mM} \mathrm{CaCl} 2$ and 


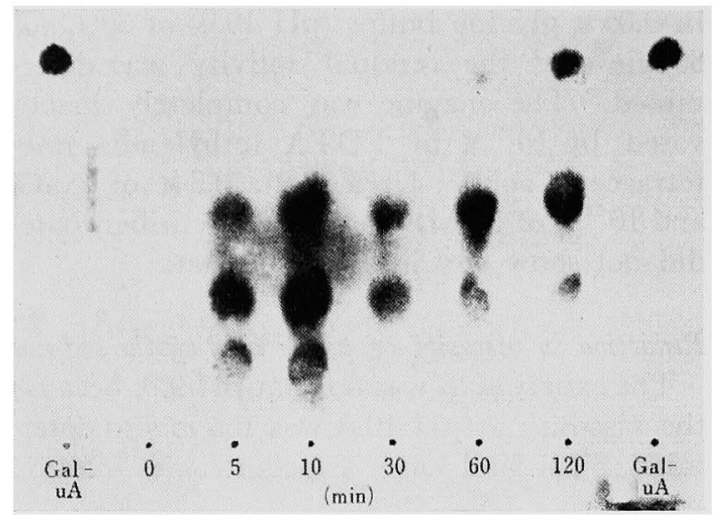

FIG. 12. Mode of Action of the Enzyme on Pectic Acid.

About $11 \mathrm{U}$ of the enzyme were added to $1 \mathrm{ml}$ of $10^{\circ}$ pectic acid solution $(\mathrm{pH} 10.0$, adjusted with $\mathrm{NH}_{4} \mathrm{OH}$ ), and incubated at $40^{\circ} \mathrm{C}$. The hydrolyzates were chromatographed on Whatman No. Papers, and sprayed with ammoniacal silver nitrate.

its $\mathrm{pH}$ was adjusted to 10.0 with $\mathrm{NH}_{4} \mathrm{OH}$. To the pectic acid solution was added to 0.1 $\mathrm{ml}$ of the enzyme $(11 \mathrm{U})$ and the mixture was incubated at $40^{\circ} \mathrm{C}$. Aliquots of the reaction mixture were periodically withdrawn and chlomatographed on Whatman No. 1 paper using the solvent system of butanal-acetic acid-water $(2: 1: 1 \mathrm{v} / \mathrm{v})$. The reducing sugars were detected by spraying with ammoniacal silver nitrate. The results are shown in Fig. 12, indicating the liberation of di-, tri- and tetragalacturonic acids in ten minutes incubation. After $2 \mathrm{hr}$, tetragalacturonic acid disappeared and the accumulation of galacturonic acid was observed concomitantly.

Other enzymatic activities of the purified enzyme Pectinesterase, pectin trans-eliminase and polygalacturonic acid trans-eliminase were not detected under the tested conditions.

\section{DISCUSSION}

The strain of Bacillus No. P-4-N isolated from soil produced new APGase in alkaline media. This strain grows well in alkaline media rather than neutral media. The morphological and cultural chracteristics of this strain will be compared with other strains including other alkalophilic bacteria reported previously. ${ }^{1,21}$ The APGase was produced only in alkaline media containing pectin; the formation of the enzyme seems to be inducible. Manganese was an important factor to stimulate the enzyme production, although no remarkable change was observed in growth of the bacteria. The APGase was partially purified by Sephadex G-100 gel filtration and DEAEcellulose chromatography, followed by Sephadex G-200 gel filtration. It is not clear whether the purified APGase is a homogeneous protein or not, because ultracentrifugal analysis, freeboundary electrophoresis, and disc electrophoresis, and disc electrophoresis have not yet been done. Endo reported that endopolygalacturonase of Coniothyrium diplodiella ${ }^{91}$ was a mixture of three endo-polygalacturonases. There is a possibility that the purified APGase is a mixture of two or more enzymes. Further works on these points are now under investigation. The enzyme is active only in the presence of $\mathrm{Ca}^{2+}$; only 10.5 of activity was detected in the absence of $\mathrm{Ca}^{2+}$ and EDTA showed $100 \%$ inhibition. Calcium ion also has an effect on stability of the enzyme; the residual activity was about $100{ }^{\circ}$, when heated at $70^{\circ} \mathrm{C}$ in the presence of $5 \mathrm{mM} \mathrm{CaCl}{ }_{2}$, and $60^{\circ} \mathrm{C}$ in the absence of $\mathrm{CaCl}_{2}$. Polygalacturonases of $C$. diplodiella ${ }^{9,101}$ were completely inactivated by heating at $60^{\circ} \mathrm{C}$ for $10 \mathrm{~min}$. Clostridium felsineum ${ }^{11}$ polygalacturonase was somewhat thermostable; about $120^{\circ}$ of activity remained after being heated at $60^{\circ} \mathrm{C}$ for 20 min. Therefore, the APGase seems to be thermostable. The enzyme has optimum $\mathrm{pH}$ at 10 toward pectic acid. This value is higher than those of polygalacturonases so for reported.

Deuel and Stutz ${ }^{121}$ classified polygalacturonase into three types, although every type may contain polygalacturonases of different specificities and properties. Type 1, the 
liquefying polygalacturonases, which split the glycosidic linkages more or less at random. They preferentially attack pectins of low degree of esterification. Type 2, they preferentially attack pectins of high degree of esterification. Type 3, saccharifying enzyme, which hydrolyzes pectins only from one end of the chain molecule. If the purified enzyme is a single entity, the APGase of Bacillus No. $\mathrm{P}-4 \mathrm{~N}$ seems to belong to a type 1 , a type of liquefying polygalacturonase.

As the results, I wish to conclude that the APGase is different from the polygalacturonases so far reported, especially in optimum $\mathrm{pH}$.

Acknowledgements. I thank Dr. Y. Ikeda for his suggestion and critical reading of the manuscript. Thanks are also due to Mrs. Y. Shishido for her skillful assistance.

\section{REFERENCES}

1) K. Horikoshi, Agr. Biol. Chem., 35, 1407 (1971).

2) K. Horikoshi, ibid., 35, 1783 (1971).

3) N. R. Smith, R. E. Gordon, and F. E. Clark, "Aerobic Sporeforming Bacteria," U.S. Dept. of Agriculture, 1952.

4) R. S. Breed, E. G. D. Murray and N. R. Smith, "Bergey's Manual of Determinative Bacteriology," Williams and Wilkins Co., Baltimore, U.S. A., 1957.

5) J. R. Sumner and G. F. Somers, "Laboratory Experiments in Biological Chemistry,' Academic Press, New York, U.S. A., 1944, p. 3435.

6) F. Weber and H. Deuel, Trav. Chim. Aliment Hyg., 36, 368 (1945).

7) O. Warburg und W. Christian, Biochem., Z., 310, 384 (1942).

8) J. R. Whitaker, Anal. Chem., 35, 1950 (1963).

9) A. Endo, Agr. Biol. Chem., 28, 551 (1964).

10) A. Endo, ibid., 28, 535, 543 (1964).

11) A. Kaji, ibid., 20, 8 (1956).

12) H. Deuel and E. Stutz, Adv. Enz., 20, 341 (1958). 